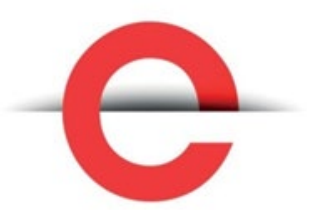

U T S

e PRE S S

Cosmopolitan

Civil Societies: an

Interdisciplinary

Journal

Vol. 12, No. 1

2020

\section{(c) (1) (2)}

(C) 2020 by the author(s). This is an Open Access article distributed under the terms of the Creative Commons Attribution 4.0 International (CC BY 4.0) License (https://

creativecommons.org/licenses/by/ $4.0 /$ ), allowing third parties to copy and redistribute the material in any medium or format and to remix, transform, and build upon the material for any purpose, even commercially, provided the original work is properly cited and states its license.

Citation: Teixeira, C. P. 2020.

Networked Technopolitics: immigrant integration as citybranding. Cosmopolitan Civil Societies: an Interdisciplinary Journal, 12:1, 67-82. https://doi.org/10.5130/ccs.v12.i1 $\underline{.6966}$

ISSN 1837-5391 | Published by UTS ePRESS | https://mcs. epress.lib.uts.edu.au
REFEREED PAPER

\section{Networked Technopolitics: immigrant integration as city-branding}

\section{Caio Penko Teixeira}

University of Milano-Bicocca, Milan, Italy

Corresponding author: Caio Penko Teixeira, Department of Sociology and Social Research, University of Milano-Bicocca, Piazza dell'Ateneo Nuovo, 1, 20126 Milano MI, Italy. c.teixeira@campus.unimib.it

DOI: https://doi.org/10.5130/ccs.v12.i1.6966

Article History: Received 23/12/2019/; Revised 20/06/2020; Accepted 27/06/2020;

Published 20/07/2020

\section{Abstract}

The article explores the role of network-led policymaking with a focus on immigrant integration. Drawing on the EUROCITIES Integrating Cities Charter, it sheds light on how immigration-related diversity governance plays a part in the city-branding strategies. The relevance of policy advocacy through the lens of cosmopolitan urbanism is instrumental for studying the governance of migration and diversity in the age of integration paradigm. Contemporary local policymaking in immigrant integration shaped by city-to-city cooperation tell us about policy models associated to cities' image. Therefore, city branding strategies framed on behalf of networked technopolitics represent a challenging way to study the immigrant integration approach. This exploratory study is based on desk research with an emphasis on literature review and documentary analysis.

\section{Keywords}

Immigrant integration, City-branding, Policy network, Governance, Diversity

DECLARATION OF CONFLICTING INTEREST The author(s) declared no potential conflicts of interest with respect to the research, authorship, and/or publication of this article. FUNDING This paper was produced without funding. 



\section{Introduction}

Cities, towns and municipalities, rather than countries, are increasingly becoming the major actors of immigrant integration policies. Concurrently, growing concerns over the social inequality and a lack of inclusive communities in western societies have stimulated policies that are aimed at promoting active forms of immigrant integration. The interplay between migration and inequality has highlighted the impact of uneven urban development on people on the move. Inequality in income, earnings, and wealth concerns in a globalised world assess the connection between the economy and political regimes (Milanovic 2016; Picketty 2014). Transnational migration is clearly intertwined with a wider picture in the making of social inequality (Faist 2016; Black et al. 2005). The link of inequality and migration 'suffers from profound methodological nationalism' (Bastia 2013). For Bastia (2013), the economic and social inequality analyses within migration study scholarships had under-explored the place-based context of inequalities, privileging data on social inequality and stratification collected mostly at a national level. It is important then to look at local integration policies.

Although the point is not to make a claim in favor of a 'methodological localism' (Zapata-Barrero et al. 2017), it is necessary to highlight the policy responses that have attempted to address the link between inequality and migration on a local socio-spatial scale (Cassiers \& Kesteloot 2012). In European cities, attention has been paid to inequality and immigration (Trenz \& Triandafyllidou 2017; Zapata-Barrero et al. 2017; Alba \& Foner 2015; Hackett 2013). Recent literature on inequality in the face of greater ethno-racial diversity, for example, highlights the relations between immigration strategies, policies and forms of integration governance (Duszczyk, Pachocka \& Pszczółkowska 2020). A significant part of global urban injustice in its contemporary form builds on international migration (Schiller \& Çağlar 2009). Diversity, equality and social inclusion have become an integral part of local integration policies against social inequality. Cities are not only developing but also sharing practices and initiatives towards immigrant integration. This approach may be viewed as part of the wider 'local turn' in migration-related diversity governance (Zapata-Barrero et al. 2017), which establishes a breeding ground for city-to-city cooperation.

Many cities are now taking a long-term approach to address the socio-economic differences that target immigrant populations, focusing on issues of diversity and nondiscrimination. Such a long-term approach may be associated with local integration policies that offer 'concrete strategies and measures of urban development' (Hillmann 2018, p. 87). This view suggests that integration policies are linked to urban development approaches under a variety of migration-led regeneration initiatives (Hillmann 2018). Integration policies are embedded in a larger dynamic urban hierarchy in today's globalisation, which clarifies how global integration of cities involves international migration of high- skilled and lowskilled workers (Sassen 2005). It is a strategic component of cities in the world economy that creates novel forms of power and politics. In the European context, Carmel and Cerami and Papadopoulos (2011) have pointed out the co-existing modes of integration and segregation, in which labor market conditions and welfare provisions play an instrumental role in how immigrants' inclusion and integration are shaped, so that 'the interaction of welfare regime, 
informal and formal labour markets (and their relationship), and immigration and citizenship regimes combine to form distinct national migrant integration regimes' (Papadopoulos 2011, p. 42).

Immigrant integration relates to city-branding strategies. City-branding is a process by which the 'city is given ontological status as a "personality" with identity and values' (Stiegel \& Frimann, 2006). It is instrumental to look at processes and dynamics of how immigrant integration is impacting city-branding strategies. The extent to which integration policies play a part in city-branding strategies matters because this tells us about how international migration became a local government effort. In this wider context of migration-related diversity governance, many transnational city networks are emerging (Oomen 2018). The EUROCITIES Integrating Cities Charter is an illustrative case of a capacity building initiative program with a network-oriented approach that enables city-to-city cooperation. This case informs us about the role of policymaking communities and how networks of policy advocacy incorporate a rhetoric of neutrality establishing standardised policy objectives. This exploratory study is based on desk research with an emphasis on review of the literature and documentary analysis. It covers a broad range of research reports, articles, policy briefs, case study findings, social media, webinar and other documents, and draws attention to city-branding strategies in local immigrant integration policies under networked technopolitics.

In this article, I argue that the EUROCITIES Integrating Cities Charter (hereafter the Charter) is not merely capacity-building and cooperation-inducing network; it is also a political regulation strategy, as it explicitly calls for adopting and implementing a specific integration model in response to immigrant-related inequality. Integration policies at the local level are turned into what EUROCITIES has been calling a 'good governance' approach, shaping signatory cities' integration models. At stake is the 'fast-traveling policy models' (Peck \& Theodore 2015) and its implications for city-led solutions to immigration and diversity management. The networked technopolitic help us to have a better understanding of contemporary migration governance. I structure the article as follows. The first section introduces the Charter, outlining how this policy network works to foster immigrant integration model shaping policies and practices at the local level. The second section explores the intersectional approach between inequality and migration that frames the integration as part of the cities' response to global dynamics of social inequality involving immigration. The third section examines the branding literature in urban studies (Dinnie 2011; Vanolo 2017) looking at cosmopolitan urbanism (Sandercock 2006). Cities are creating an urban brand of immigrant integration, which is based on (imported or borrowed) policy models and designs. Finally, future directions for research are suggested before concluding remarks.

\section{Immigration Governance in a Moving World}

Immigrant integration involves several complexities including challenges to governance and policymaking through a set of institutional interactions that stretch across scales and can be traced analytically in documents, discourses, practices, regulations. The question of how to 
improve the 'management' of immigrants as a local level effort has been mobilising great power between European cities. City-to-city cooperation can be seen through the 'transnational city networks' fostering immigrant integration. Oomen (2019) talks about immigration-related 'transnational city networks' exploring the impact of these arrangements into local governments. These networks provide support and guidance and they are facilitating the mutual exchange of information based on their experience in integrating refugees and migrants. Importantly, 'networks allows cities to decouple their local policies from those developed nationally, and their pragmatic, symbolic, and jurisgenerative activities enable them to better manage migration, to contest the current migration regime, and to even modify it' (Oomen 2019, p. 22).

Among other 'transnational city networks', the Charter, launched in 2010, includes 39 signatory cities addressing immigrant integration policies and practices. City-to-city cooperation lies at the heart of this network and serves as the basis for influencing the decision-making process at the subnational level regarding immigrant integration. It aims to frame city-level policies and practices for diversity management based on research evidence and policy model adoption that targets non-discrimination and equal opportunities for city residents, particularly immigrant needs (EUROCITIES 2017, 2013, 2012). It builds on policy learning, standards monitoring, evaluation and implementation procedures to integrate newcomers characterised by the city-to-city cooperation between localities experiencing common issues on migration-related diversity (EUROCITIES 2017, 2013, 2012).

This policy network establishes key features for policy design and initiatives to assess in standardised terms of quality and performance with the purpose of enhancing migration diversity management outcomes. By supporting city-level responses to migration-related diversity governance issues, it puts the city-to-city cooperation with focus on monitoring and peer learning at the centre of the local immigrant integration policy model. By analysing the Charter, Moloney and Kirchberger (2010) argued that peer reviewing and benchmarking are the key tools for mutual learning that reveal a mobilising strategy, coordinating efforts. Their analysis found that the Charter pushes an agenda on immigrant integration policies and allows cities to play a meaningful role in the network, and consequently, the network itself also has significant influence over a city's agency.

The Charter has been disseminating good practices of comparable policies based on benchmarking approach between signatory cities. It monitors and evaluates local policy performances and its achievements. This process of peer reviewing and benchmarking assumes a discourse of political neutrality which applies adequate instruments and standardised procedures informed by an evidence-based policy- making agenda. This policy network defines a model for inclusive city building. Such a model identifies priority areas to improve policy integration and draws from practical solutions and challenges faced by the signatory cities, including stakeholders such as non-profits and local communities organisations. As a policy network, it recognises the crucial role of actors at the local level and how cities are the front lines of immigrant integration. It establishes shared policy objectives to create a model of inclusive urban policies and local services to newcomers. Within the 'integrating cities' rhetoric, it sets out a vision over long-term steps in the realm of 
migration-related diversity policies towards coordinated approaches. The signatory cities receive recognition for their efforts to create inclusive cities. Hambleton (2014) argued that the Charter might be seen under the local integration strategies by which guidelines offered a common background of policy commitment and practical lessons learned. This enabled mutual learning as a promising model for an inclusive response to the context of inequality through urban placemaking of diverse communities (Hambleton 2014).

The Charter has influenced the local approach to integration in different ways. For example, 'Nuremberg, who signed the charter in October 2015, uses the charter as a benchmark to evaluate its policies' (EUROCITIES 2015, p. 16). Aspects of the Charter included into the political representatives' discourse shows that Helsinki 'promoted the charter within the city and the broader metropolitan area through speeches and official presentations at seminars and other events' (EUROCITIES 2013). Further:

\begin{abstract}
Ghent used the charter as a basis for the Action Plan on Diversity 2020 which sets the objective of $30 \%$ of employees with a migrant background. It has also been used to raise awareness on implementing equal opportunities and poverty reduction in local policy with training for current employees. Leipzig used the charter to foster the integration process in general and to promote the implementation of measures, actions and recommendations. In Oslo, the charter underpins city policies, especially for the OXLO guide for equal access to services and the OXLO Business Charter (EUROCITIES 2018, p. 18).
\end{abstract}

The Charter plays an important role in shaping local integration policies. The implementation of these policies involves a branding-strategy with emphases on diversity and welcoming as part of the city's identity and reputation. There is a branding aspect of the process that has become one significant component of policy shift in integration discourses and practices. The policy network adds 'value' to the local public policymaking. And the policy network calls for greater regulation of immigrant integration policies at the local level to ensure program effectiveness, which remains a task deeply structured in technocratic approaches to policy design in the areas of cooperation and sharing. Examining the Charter, we understand how immigrant integration policies respond to immigration-related inequality.

\title{
Intersecting Migration and Inequality
}

The rising social and economic inequalities across the world remains a central issue at the level of the nation-state (Milanovic 2016). As Kerbo (2003) indicated, inequality encompasses class, race and gender and it is also about a condition of unequal access to resources related to broader processes of social division, hierarchy, and social differences. Inequality does not reduce an apolitical distribution of wealth and income. Rather, it is socially constructed through social relations of exploitation, contradictions and political power. Within this debate on global inequality, some studies focused on Western European countries indicated the fundamental link between inequality, labour market changes, and financial globalisation (Heath \& Cheung 2007; Long 2014). Long (2014) considers the impact of migration on inequality and challenges the assumption of migration as a driving force to inequality. For her, migration had potentially important effects to address certain features of the rising inequality in Western societies. She outlined the potential benefits of 
labour migration and labour mobility to address social inequality in which the exclusion of immigrants from the formal labour market is implicated as one key feature.

The international migration movements are part of a wider frame of uneven wealth distribution that contributes to greater social inequality between the richest and poorest countries. The relation between migration and inequality may consider not only an economic perspective but often includes a traumatic context of social changes, such as authoritarian political regimes, civil war, persecution, environmental hazards. As migration occurs in deep poverty and violence, the migrant labour exploitation in Global North countries is framed through precarious lifeworlds, in which immigrant experience of vulnerability becomes subject to neoliberal work and welfare regimes, engendering global inequality dynamics (Lewis 2015). Forced migration has played an important role in inequality studies. Crucial to an understanding of international migration movements is the awareness that the precarious life worlds of migrants are linked to geopolitical dynamics of uneven urban development under neoliberal globalisation.

Inequality demonstrates an instrumental economic side, through which it reveals the social logic of exploitation. Income inequality holds social implications. Inequality is not a subject outside the historical processes of wealth accumulation and political power established by dispossession, displacement, and abandonment. Social inequality concerns the ways in which income inequality implies power relations through which people are organised in terms of domination and oppression. This means that the logic of social inequality is inherently a political matter related to social vulnerabilities. More recently, the debate about social inequality has been concerned with migration-development interplay. The intersectional perspective on migration-development considers how internal and cross-border migration can be analyzed through the lens of urbanised globalisation.

For Bastia (2013), the perspective of intersectionality informs us about how oppression and privilege outline different categories of disadvantage related to social inequality. Social inequality as a dynamic process is integrated with gender, class, ethnicity, and race issues. Such a viewpoint has considered inequality not only as 'historically grounded' but also assumes a 'context-specific analysis of social relations of difference to avoid depoliticising and simplifying complex realities' (Bastia 2013, p. 245). The inequality-migration interplay leads to another central point about the way in which migration can have a negative or positive correlation with inequality. According to Bastia (2013), the relation between migration and inequality is always contextual, so that it is necessary to explain which type of inequality is at stake. She highlighted the importance of inequality and transnational migration beyond income-based measures. Having said this, inequality is closely connected to organising positions of privilege where people gain and maintain material and non-material unequal distributions of wealth, rights, and recognition. The migration-development nexus lies in an analysis in which social inequality refers to sites where multiple forms of oppression or privilege intersect, including material and social measures (Bastia 2013).

Policymaking in immigration, integration and social cohesion continue to frame key debates on social inequalities and have more significant leverage in integrating immigrants 
into the economic and social spheres. These policies are formulated, operationalised and implemented in line with development theories and broader ideological perspectives, focusing on the role of immigrants in their host communities. To think about the Charter, the migration-development and social inequality perspectives have helped to understand the way inequality shapes immigration and integration policies. Under the Charter, cities are seen as part of a wider diversity-management governance that uses a bottom-up approach for managing social inequalities, emphasising a welcoming city image to bolster local economies through a combination of local-based practices and policy coordination between signatory cities. An intersectional view of social inequality is also significant for migrant integration policies. The Charter has made it a priority to address immigrant integration as a social and economic task ranging from labour market issues to anti-discrimination policies to enhance the public perception on migration and diversity. In this way, immigrant integration is part of the response to social inequality.

\section{Networking, integrating and branding}

Integrating immigrant newcomers as part of the nation-building processes in Europe have been debated for a long time (Favell 2003). The nationalised idea of integration is about an inclusion of a newcomer immigrant or a member of a marginalised group into a 'society' while it is ultimately bounded by a nation-state in terms of a national identity project (Favell 2003). The goal of integration policies involves the management of 'ethnic' immigrant populations, who are non-Europeans. It is a matter of government practices and discourse, an ideal linked to the nation-building process under the growing condition of cultural diversity (Favell, 2003). There has been a great debate on the role of local authorities and different local actors in the immigrant integration approach. In view of this, cities have been playing an important role in integration policies (Zapata-Barrero et al. 2017). According to this view, the governance of migration-related diversity has its clearest expression at the city level, where conflicts arise from social inequalities, power relations and racism.

Schinkel's critique of immigrant integration clarifies the way integration discourses reveal forms of imagining society. It talks about integration and the unit, social cohesion, and importantly, the matter that is jeopardising it $(2017,2018)$. Schinkel argued that society vis-àvis 'immigrant community' 'only ever exists through an active work of the difference, separating a supposed "inside" from an "outside", of circumscribing - by means of a work of power-knowledge - who and what is and is not "part of society"' $(2018$, p. 9). Schinkel (2017) argues that integration is both the political way of separating populations and identities as 'others' and afterwards of determining how to include them into a prescriptive and standard account of society. On the one hand, immigrant integration becomes a tool for 'othering' people through its forms of governing that are constructed on group-based differences and forms of identity in social life (Schinkel 2018). On the other hand, how local governments deal with issues of immigration, diversity, and integration is essential for economic growth and urban development: 'Diversity, if managed well through immigrant integration, is seen as an opportunity to create and foster an image of the city, which makes it attractive for foreign investment, tourism, and increased consumption' (Hadj Abdou 2019, p.5). Diversity is central to understanding the extent to which the governance technique of 
immigrant integration and the knowledge produced around it: 'tend to reproduce and reorganise 'race' in the city through processes of racialisation and a re-making of the racial subject' (Hadj Abdou 2019, p.6).

The Charter acts as an illustrative example of this governance model of ethno-cultural diversity for cities. This immigrant integration model considers the migration-inequality nexus at the local level through policy network embedded in the cosmopolitan approach. For Sandercock (2006 p. 39), cosmopolitan theorising helps us to clarify the discourse 'around managing our peaceful coexistence in shared spaces'. Rather than insisting on fostering some 'sense of belonging and the imperative of peaceful coexistence', Sandercock (2006) argues that cosmopolitan urbanism might be based on agonistic democratic politics. Cosmopolitan urbanism has a political dimension regarding the right to difference in the city dealing with conflicts not accommodating them for the sake of economic strength of the city (Sandercock 2006). It is concerned with the (utopian) politics of an urban imaginary structuring political life and managing cultural diversity (Sandercock 2006). The Charter may be associated with a wider branding strategy of cities, which has been translating a cosmopolitan imaginary into discourses and practices of migration-related diversity governance. This underlines that cosmopolitan urbanism works as the background of the city branding strategies to promote a model to shape policy practices for managing immigrant integration under the umbrella of migration-related diversity policies.

The strategies and tactics of city branding influence governmental choice in migrationrelated diversity governance. Integrating becomes a brand for cities, which mostly take a rights-based perspective regarding institutional discourse, practices, and policies that shape the urban imaginary of cities. Place branding is related to international politics in the global policy process (Van Ham, 2008). Branding-strategies lead cities to adopt new strategies and tactics in delivering a message that involves values, goals and desires through propaganda and public diplomacy (Van Ham, 2008). Place branding is arguably, at its most basic level a political value-set that is concerned with the practice of image-making and reputation management (Van Ham, 2008). This proves useful in understanding the relevance of the governance of migrant-related diversity. At the broadest conceptual level, city branding strategies are also an aspect of soft power related to policy processes of immigrant-related diversity.

Soft power concerns the nature of power relations and it results from a voluntary process of regulation, co-option, and cooperation between actors. Nye (1990) coined the term 'soft power' to analyze the American international politics after the Cold War, characterised both by attraction and persuasion. Soft power influences decision-making and shapes policies and policy regimes and its 'softness' describes the processes of governing without explicit coercive tools (Nye, 1990). It implies, somehow, a kind of 'free and voluntary' joint action among social actors (Nye 1990). In a more recent view on soft power, Nye (2019) extended the concept by including non-coercive methods of negotiation including public diplomacy, global image and influence. For Hayden (2012), soft power is articulated in public diplomacy in the international system. Both as discourse and practice, soft power puts communication and information at the heart of public diplomacy (Hayden 2012). However, soft power is no 
longer only a matter of the country's national level shaping the agency of political actors via foreign policy tools. Indeed, subnational soft power and local public diplomacy cities are at the forefront on a wide range of policies in democracies and we need to understand and advance the critical role of local governments in networked field of transnational political action, such as city-to-city cooperation.

City-to-city cooperation is often intimately related to the various processes that exemplify soft power in shaping cities' images. This cooperation involves branding-strategies as a way for rethinking policymaking through policy models. Policy models embedded in both networks and within multiple local contexts have been articulated in western European city-regions. From the perspective of the soft politics of city branding, the significance of horizontal networking, transnational linkages and city-to-city cooperation initiatives among local and regional states and other non-central governments and non-for-profit organisations in navigating and negotiating difference becomes clear. It is no surprise, therefore, that city branding influences policymaking processes. Bookman (2018) notes that cities as branded entities gain distinction in terms of urban culture, social life, and consumption, and this is the case for many postindustrial urban regeneration strategies. Research has shown how the discourses of cities and local governments are working for the promotion of immigrant entrepreneurs and fostering a welcoming environment in terms of the use of public space and city services (Aytar \& Rath 2012). For cities experiencing 'super-diversity', migration, ethnic minority groups and cultural diversity become key themes for a local agenda with policies of integration: 'an awareness of the new super-diversity suggests that policy-makers and practitioners should consider new immigrants' plurality of affiliations' (Vertovec 2018, p. 117), not just their ethnicity.

Jordan and Schout (2006) argued that EU policy coordination was based on a networked governance structure that was less dependent on the power of hierarchical rulemaking authorities. Importantly, networked governance relies on the cooperation through joint action. In doing so, networked governance frames a political, procedural and legal regulatory arrangement that shapes policy formulation and implementation (Jordan \& Schout 2006). This regulatory arrangement can be considered not only as networked but also as an experimentalist form of governance that focuses on soft power and voluntary commitment (Maggetti 2015). This leads to the last point. Place branding strategies play an important role in the 'soft power' dynamics over policymaking via 'policy models' as a result of advocacy and persuasion. For Peck and Theodore (2015), the policymaking field has become influenced by 'best practice' and 'paradigmatic models'. This means that policy change often is driven by models of best practice, which is 'those social practices and infrastructures that enable and sustain policy "mobility," which enable the complex folding of policy lessons derived from one place into reformed and transformed arrangements elsewhere' (Peck and Theodore 2015, p. xvii). According to this view, a policy transfer process carried out through "discursive frames and institutional frameworks perform[s] a "preceptorial" function, licensing some cognitive and political behaviors, shaping policymaking imaginaries, and enabling certain patterns of "learning," while disciplining or even excluding others' (Peck \& Theodore 2015, p.27). 
Many cities seeking to change their urban brand are supported by policy networks. In immigration-related diversity governance, the role of place branding can be seen as a transnational regulation strategy. The action of branding cities as integrative cities sets out political values and an aspirational framework for immigrant integration as it may and should become. Although not from a top-down perspective, this policy network provides practical tools and conceptual insights for migration and diversity policies. These practical insights contribute to the city's image, and immigrant integration is viewed as a relevant element of branding. An immigrant integration policy aligned to the policy network standards has a significant identity-shaping function over signatory cities in such a way that it cannot be understood as merely a technical process or considered an allegedly neutral tool or approach. Transnational city network characterised by 'fast policy' (Peck \& Theodore 2015) follows the perspective of post-political modes of governing. Mouffe (2016) notes that under the postpolitical order, the conflictual dimension of democracy is addressed by 'good governance'. Seen from this perspective, public policy models using tools of soft power are described at a surface level as taking an evidence-based approach. Yet, in reality, this approach is what is driving changes in local policy and at the same time defining what renders this policy a (politically) successful response to local conditions.

In recent years, the rise of the interplay between migration-related issues and local policymaking processes has become more apparent in the European literature, exploring 'whether and to what extent a trend towards convergence can actually be identified' (Caponio \& Borkert 2010, p. 21). City branding can help us with this issue. For Gebhardt (2014, p. 12), 'many cities are leading the way in setting up local institutions and services to reflect the diversity of those they serve, and in promoting an inclusive local identity'. As noted by Gebhardt (2014), this is the case for Copenhagen, in which the city's strategy of becoming Europe's most inclusive city included projects, training and campaigns promoting the institutionalisation of diversity in various fields of the city's services. Drawing on Amsterdam and Rotterdam, Belabas, Eshuis \& Scholten (2020) argue that 'the institutional embedding of place branding influences policy goals and content' (p.3). The point is not only bringing the city's residents together but also how to benefit from place branding to push the city-making process to greater innovation, greater competitiveness, and greater prosperity:

[P]lace branding does not only fulfil an 'internal' function of representing the entire urban population and helping all residents to identify with their city, but also an 'external' function, oriented towards businesses and tourism. Branding policies often function as a tool to increase economic development and international competitiveness instead of enhancing social cohesion or providing a shared sense of belonging amongst residents (Belabas, Eshuis \& Scholten 2020, p. 4).

These cases illustrate the promotion of diversity and equality in local policies combined with efforts of (re)branding a city's identity. These cities demonstrate commitment to managing immigrant-related diversity through services, policies, awards, campaigns, posters, and festivals. Branding-strategies are therefore to be encouraged as a tool guide for city's government to approach the analysis, formulation, evaluation and measurement of performance that informs decision-making in order to foster economic and social benefit 
from the immigration and integration policies adopted. Ultimately, the Charter reinforces the 'fast-traveling practices' (Peck and Theodore 2015) of how integration in society should be done, in its simplest formulation, with immigrant integration as a matter of policy model adoption. By influencing the policymaking process and merging a set of political values at the local level, transnational city networks play an important role in a city's brand and how it should be implemented and formulated to achieve the desired goals of the network. This also opens a channel for exchange of ideas, information, and techniques offering a roadmap for policymaking within immigration-related diversity governance. On top of these considerations, benchmarking, best practices, and peer-to-peer learning are a set of 'soft tools' shaping (local) policymakers and stakeholders, which carries within its regulatory practices, somewhat depoliticised forms of othering groups of people.

\section{Concluding remarks}

The EUROCITIES Integrating Cities Charter helps us understand how a 'transnational city network' shapes local policy responses, particularly through the lens of 'fast policy'. It highlights the need for analyzing the link between city branding-strategies and policy change. Further, through the field of immigrant integration policies, it demonstrates that it is vital to interrogate the significance of transnational city networks and the apparent policymaking consensus that shapes the city's image. In a global economy which has driven cities to compete for global investment and tourism, which are framing inequalities in the urban setting, scholarly work to further explore the immigration-integration-city's image matrix remains to be done.

The challenge is to find ways of studying how transnational city networks are handled by local government agencies and their street-level bureaucrats and shaped by immigrant organisations and grassroots organising groups standing up for rights. It is time to acknowledge that more research and informed debate on immigrant integration and its normalization of racial otherness is needed to generate new, interdisciplinary insights about policy models. Therefore, policy networks are set to play a key role in (re)producing models and making it vital for critical migration scholars to build knowledge about issues of international migration, societal diversity as well as related public policies. In these discussions, it is relevant to understand to what extent transnational city networks can foster transformative, community-driven alternatives to immigrant integration. As is clear, there is room for analyzing how themes such as participatory arrangements, accountability and social control can shed light on immigrants' political participation in the local policymaking arena, and how we read this process of institutional and policy change through the lens of deliberative democracy. We might challenge the binary divide of integration versus segregation.

It is therefore prescient to interrogate migration policy and foster an interdisciplinary research agenda on new municipalism, institutional learning, spaces of social innovation and experimentation, which underpins the complexities of and the implications for urban agency, city-making and (im)migration governance in globally linked city-regions. Work within these perspectives deals with theories from a range of disciplines and involves methodologies used 
in this field (e.g. action research, participant observation, longitudinal ethnographic research and so on). At a time when debates on immigrants' rights, refugees and policy responses continue to spread hostility toward or about people on the move, such an interdisciplinary research agenda can provide much-needed clarity and important analysis which will be of interest to city-makers, policy makers, activists and other stakeholders, including but not limited to the fields of urban studies, city planning and social protection studies.

The commitment of a city to immigration and diversity governance cannot be detached from its branding-strategies. Transnational city networks play an instrumental part in influencing a city's image and its surrounding discourse. Although forged and configured as a post-political condition, immigrant integration models relocate political power and decisionmaking at the local level; they consitute a political program intricately enmeshed with cities. Peck and Theodore (2015) argue that 'networked technopolitics' shapes contemporary policymaking and, by so doing, it calls for democratic deliberation and popular control. Following this line of thought, I have argued that the 'transnational city network' based on 'fast policy' is also a governance technique. While others might argue that traveling (that is, transferable) models of policy development and technocratic designs of immigrant integration are examples of how transnational politics can be involved in the production of cosmopolitan urban spaces, I suggest that we perhaps need to recast our understanding of city-branding within immigration governance under a heading of 'networked technopolitics' (Peck and Theodore 2015). Taken from this perspective, the governance technique of immigrant integration reveals how the ethnic difference of the cosmopolitan 'Other' is managed through its connectedness to transnational networks, and this is far from a matter of technical knowledge for policymaking.

\section{Acknowledgement}

I am grateful for the comments from anonymous reviewers and from the editors of this special issue, which have greatly improved the manuscript.

\section{References}

Alba, R. \& Foner, N. 2016, 'Integration's challenges and opportunities in the Wealthy West', Journal of Ethnic and Migration Studies, vol. 42, no.1, pp. 3-22. https://doi.org/10.1080/1369183X.2015.1083770

Aytar, V. \& Rath, J. 2012, 'Introduction: Ethnic neighbourhoods as places of leisure and consumption', Aytar, V. \& Rath, J. (eds.), (ed.) Selling Ethnic Neighborhoods: The Rise of Neighborhoods as Places of Leisure and Consumption, Routledge, London, pp. $1-15$.

Bastia, T. (ed.) 2013, 'Migration and Inequality: an introduction', Migration and Inequality, Routledge, Abingdon.

Belabas, W., Eshuis, J. \& Scholten, P. 2020, 'Re-imagining the city: branding migrationrelated diversity', European Planning Studies, vol. 28, no. 7, pp. 1315-1332. https://doi.org/10.1080/09654313.2019.1701290

Black, R., Natali. C. \& Skinner, J. 2005, Migration and Inequality, Technical Report, World Bank, Washington, DC. https://openknowledge.worldbank.org/handle/10986/9172 
Bookman, S. 2018, Brands and the City: Entanglements and Implications for Urban Life, Routledge, Abingdon

Caponio, T. \& Borkert, M. (eds.) 2010, Local Dimensions of Migration Policy Making, Amsterdam University Press, Amsterdam.

Carmel, E., Cerami, C. \& Papadopoulos, T. (eds.) 2011, Migration and Welfare in the New Europe: Social Protection and the Challenges of Integration, Policy Press, Bristol.

Cassiers, T. \& Kesteloot, C. 2012, 'Socio-spatial inequalities and social cohesion in European cities', Urban Studies, vol. 49, no. 9, pp. 1909-1924. https://doi.org/10.1177\%2F0042098012444888

Dinnie, K. 2011, 'Introduction to the theory of city branding', in Dinnie K. (ed), City Branding, Palgrave Macmillan, London. https://doi.org/10.1057/9780230294790

Duszczyk, M., Pachocka, M., \& Pszczółkowska, D. (eds.) 2020, Relations between Immigration and Integration Policies in Europe: Challenges, Opportunities and Perspectives in Selected EU Member States, Routledge, Abingdon. https://doi.org/10.4324/9780429263736

EUROCITIES. 2012, Integrating Cities Toolkit: enhancing public perception on migration and diversity. EUROCITIES, Brussels. http://nws.eurocities.eu/MediaShell/media/Enhancing\%20public\%20perception\%20of \%20migrants.pdf

. 2013, Cities and Migrants: implementing the EUROCITIES Integrating Cities Charter. EUROCITIES: Brussels. http://nws.eurocities.eu/MediaShell/media/IntegratingCitiesReport_Cities $\% 20$ and $\% 20$ migrants \%20-final.pdf

. 2017, Labour Market integration of refugees and asylum seekers. EUROCITIES: Brussels. http://nws.eurocities.eu/MediaShell/media/Labour_market_integration_of_refugees_an d_asylum seekers.pdf . 2018, Cities and Migrants - Implementing the Integrating Cities Charter. EUROCITIES: Brussels.

Faist, T. 2016, 'Cross-border migration and social inequalities', Annual Review of Sociology, vol. 42, no. 1, pp. 323-346. https://doi.org/10.1146/annurev-soc-081715-074302

Gebhardt, D. 2014, Building inclusive cities: challenges in the multilevel governance of immigrant integration in Europe, Migration Policy Institute, Washington, DC. https://www.migrationpolicy.org/research/building-inclusive-cities-challengesmultilevel-governance-immigrant-integration-europe

Hackett, S. 2013, Foreigners, Minorities and Integration: The Muslim Immigrant Experience in Britain and Germany, Manchester University Press, Manchester. https://doi.org/10.7228/manchester/9780719083174.001.0001

Hadj Abdou, L. 2019, Immigrant integration: the governance of ethno-cultural differences, Comparative Migration Studies, vol. 7, article 15. https://doi.org/10.1186/s40878-019$\underline{0124-8}$

Hayden, C, 2012, The Rhetoric of Soft Power: Public Diplomacy in Global Contexts, Lexington Books, Lanham, MD. 
Hambleton, R. 2014, Leading the Inclusive City: Place-based Innovation for a Bounded Planet, Policy Press, Bristol. https://doi.org/10.1332/policypress/9781447304975.003.0001

Heath, A., \& Cheung, S. Y. (eds.) 2007, Unequal Chances: Ethnic Minorities in Western Labour Markets, Oxford University Press, Oxford.

Hillmann, F. 2019, 'Instigating integration', Topos: European Landscape Magazine, vol. 108, pp. 84-89.

Kerbo, H. 2003, Social Stratification and Inequality: Class Conflict in Historical and Global Perspective, $5^{\text {th }}$ ed. McGraw-Hill, London.

Lewis, H., Dwyer, P., Hodkinson, S. \& Waite, L. 2015, 'Hyper-precarious lives: Migrants, work and forced labour in the Global North', Progress in Human Geography, vol. 39, no. 5, pp. 581-585. https://doi.org/10.1177/0309132514548303

Long, K. 2014, The Huddled Masses: Immigration and Inequality, Thistle Publishing, London.

Milanovic, B. 2016, Global Inequality: A New Approach for the Age of Globalization, Harvard University Press, Cambridge, MA.

Nye, Jr., J. 2019, 'Soft power and the public diplomacy revisited', The Hague Journal of Diplomacy, vol. 14, nos.102, pp. 7-20. https://doi.org/10.1163/1871191X-14101013

Moloney, T. and Kirchberger, A. 2010, Cities Accommodating Diversity: Findings and Recommendations from the Peer Review Project "Diversity and Equality in European Cities", EUROCITIES and Migration Policy Group http://www.migpolgroup.com/public/docs/171.CitiesAccommodatingDiversity DIVE 22.02.10.pdf

Oomen, B. 2019, 'Decoupling and teaming up: The rise and proliferation of transnational municipal networks in the field of migration', International Migration Review, published online, 4 November, pp. 1-27 https://doi.org/10.1177/0197918319881118

Papadopoulos, T. 2011, 'Immigration and the variety of migrant integration regimes in the European Union', in Carmel, E., Cerami, C. \& Papadopoulos, T.(eds.), Migration and Welfare in the New Europe: Social Protection and the Challenges of Integration, Policy Press, Bristol, pp. 23-48.

Peck, J. \& Theodore, N. 2015. Fast Policy: Experimental Statecraft at the Thresholds of Neoliberalism, University of Minnesota Press, Minneapolis.

Picketty, T. 2014, Capital in the Twenty-First Century. Harvard University Press, Boston, MA.

Sassen, S. 2005, 'The Global City: introducing a concept', Brown Journal of World Affairs, vol. 11, no. 2. pp. 27-43. http://www.saskiasassen.com/pdfs/publications/the-globalcity-brown.pdf

Schiller, G. N. \& Çağlar, A. 2009, 'Towards a comparative theory of locality in Migration Studies: Migrant incorporation and city scale', Journal of Ethnic and Migration Studies, vol. 35, no. 2, pp. 177-202. https://doi.org/10.1080/13691830802586179

Schinkel, W. 2018, 'Against 'immigrant integration': for an end to neocolonial knowledge production', Comparative Migration Studies, vol.6, article 31.

https://doi.org/10.1186/s40878-018-0095-1 
Stiegel, J. \& Frimann, S. 2006, 'City Branding - All smoke, no fire?' Nordicom Review, vol. 27, no. 2, pp. 245-268. https://doi.org/10.1515/nor-2017-0241.

Trenz, H-J. \& Triandafyllidou, A. 2017, 'Complex and dynamic integration processes in Europe: Intra EU mobility and international migration in times of recession', Journal of Ethnic and Migration Studies, vol. 43, no.4, pp. 546-559. https://doi.org/10/1080/1369183X.2016.1251013

Vanolo, A. 2017, City Branding: The Ghostly Politics of Representation in Global Cities, Palgrave Macmillan, London. https://doi.org/10.4324/9781315660660

Vertovec, S. 2010, 'Towards post-multiculturalism? Changing communities, conditions and contexts of diversity', International Social Science Journal, vol. 61, no. 199, pp. 83-95. https://doi.org/10.1111/j.1468-2451.2010.01749.x

Zapata-Barrero, R., Caponio, T. \& Scholten, P. 2017, 'Theorizing the "local turn" in a multilevel governance framework of analysis: a case study in immigrant policies', International Review of Administrative Sciences, vol. 83, no. 2, pp. 241-246. https://doi.org/10.1177/0020852316688426 